УДК 338.5:633.11:631.526.3.001.4

(C) 2014

Плаксієнко В. Я., доктор економічних наук, професор, Гладіліна Т. В., аспірант

(Науковий керівник - доктор економічних наук, професор В. Я. Плаксієнко)

Полтавська державна аграрна академія

\title{
НАУКОВО-ОРГАНІЗАЦИЙНІ АСПЕКТИ ФОРМУВАННЯ ВИТРАТ НА ПРОВЕДЕННЯ ДЕРЖАВНОГО СОРТОВИПРОБУВАННЯ СОРТІВ ПШЕНИЦІ ОЗИМОї
}

\section{Рецензент - доктор економічних наук В. В. Писаренко}

У статті визначено формування структури витрат на проведення Державного сортовипробування сортів пиениці озимої в селекційних $i$ науководослідних установах (на базі селекиійного цеентру ПДАА) та розглянуто правове забезпечення проведення Державного сортовипробування сортів рослин в Украйні з метою діагностування й вдосконалення шляхів формування витрат на створення сорту 3 використанням інноваційних методів селекиії пшениціі озимої, щзо впливають на розвантаження селекційного процесу у просторі й часі, на зменшення витрат селекційного прочесу, ефективнішого використання сортових рослинних ресурсів селекційних установ та підвищення науково-технічного рівня виробництва зерна.

Ключові слова: селекційний прочес, витратно-иіновий механізм створення сортів, структура витрат, Державне сортовипробування, Державна система з охорони прав на сорти рослин, правове забезпечення.

Постановка проблеми. Україна - один із потужних виробників сільськогосподарської продукції у світі, тому підвищення потенціалу врожайності культур та валових зборів у рослинництві має загальнодержавне значення.

Фундаментальним напрямом підвищення врожайності зернових культур є впровадження сортів інтенсивного й високоінтенсивного типів [1]. За підрахунками зарубіжних учених, нині приріст урожайності зернових на $50 \%$ досягається за рахунок впровадження нових сортів, а $50 \%$ - за рахунок удосконалення технології вирощування. Відповідно до висновків експертів ФАО, протягом найближчих 30 років весь світовий приріст виробництва продукції рослинництва досягатиметься за рахунок селекції, тобто, новостворених сортів, їхніх нових властивостей і якісних параметрів.

Останніми роками вітчизняною селекцією створено низку нових сортів пшениці озимої. Вони різняться між собою морфологічними ознаками, біологічними властивостями, ступе- нем інтенсивності, якісними показниками; мають певну функціональну зорієнтованість стосовно агроекологічних умов вирощування, різний адаптивний рівень стійкості до несприятливих факторів зовнішнього середовища. Поява сортів iз принципово новими характеристиками, ефективне використання їх генетичного потенціалу, зменшення енерговитрат на виробництво зерна потребує вдосконалення системи добору технології селекційного процесу та раціонального розміщення сортів у певних грунтово-кліматичних зонах.

Глибоке знання біологічних властивостей новостворених сортів дає змогу керівникам і спеціалістам обгрунтованіше підходити до їх вибору для конкретних умов сільськогосподарського виробництва, особливо для господарств із різним рівнем родючості грунтів, відмінними технологіями вирощування, 3 неоднаковими матеріально-технічними можливостями, адже потенціал продуктивності сорту - це генетична ознака, й не кожен сорт здатний окупити врожаєм закладені витрати [1].

До Державної системи з охорони прав на сорти рослин від селекціонера надходить матеріал, який після позитивних результатів випробувань отримує офіційний статус «сорт».

За результатами випробувань формується Реєстр сортів рослин, придатних для поширення в Україні (далі - Реєстр). У Реєстрі зосереджується вся інформація щодо вимог виробника і користувача сорту. Тому важливо забезпечити ефективний зворотний зв'язок для того, щоб була змога встановлювати критерії, за якими сорти рослин заносяться до Реєстру [5].

На даний час селекційними установами, де створюються сорти, недостатньо вивчений витратно-ціновий механізм створення того чи іншого сорту сільськогосподарських культур, не відпрацьовані методики формування витрат селекційного процесу, визначення собівартості сорту. В зв'язку з цим і виникла необхідність 


\section{EKOHOMIKA}

обгрунтувати витрати на всіх етапах селекційного процесу і вивчити їх вплив на рівень економічної ефективності виробництва в нових умовах господарювання у селекційних установах.

Однією зі складових витратно-цінового механізму селекційного процесу є проведення державного сортовипробування «новостворених сортів».

Аналіз останніх досліджень і публікацій, у яких започатковано розв'язання проблеми.

Питанням діяльності Державної системи 3 охорони прав на сорти рослин, розвитку ринку сортів рослин, організації методологічних і методичних засад проведення сортодослідної роботи, інноваційних досліджень на сучасному етапі розвитку присвячено праці В.Я. Амбросова, Н. Ю. Сгорова, П. Т. Саблука [5] , О. В. Захарчука [3, 5], О. М. Гончара, М. І. Кісіля [5], С. О. Ткачик, Л. М. Худолій, В. В. Юрчишина, В. Г. Андрійчука, А. В. Андрющенка та інших авторів.

Наукових робіт, присвячених дослідженню, розробці, впровадженню та удосконаленню витратно-цінового механізму селекційного процесу створення нових сортів, недостатньо, тим більше, що вихід українських селекційних установ на світовий ринок сортів потребує досконалішого інформаційного забезпечення в формуванні техніко-економічних i фінансових показників селекційного процесу, його економічного обгрунтування, дослідження правових аспектів проведення Державного сортовипробування, охорони нових сортів, захисту прав селекціонерів, права інтелектуальної власності, селекції, генетики і насінництва нових сортів України, їх державного регулювання.

Мета і завдання дослідження. Мета наших досліджень - структуризація витрат на проведення кваліфікаційної експертизи сортів рослин, починаючи 3 передачі насіннєвого матеріалу (новоствореного сорту) в державне сортовипро- бування до остаточного рішення державної комісії щодо включення його в реєстр сортів України на прикладі сортів пшениці озимої селекційного центру ПДАА, а також у розгляді правового забезпечення 3 питань проведення Державної експертизи сортів рослин в Україні.

Вирішувалися такі завдання: дослідити витратно-ціновий механізм створення сорту, вивчити структури витрат, що склалася в цілому в селекційному центрі ПДАА, кожного етапу селекційного процесу; відпрацювати методику формування собівартості сорту.

Матеріали і методи досліджень. Основними джерелами інформації для написання статті стали наукові праці вітчизняних економістів, селекціонерів, світова практика, законодавча база України, а також дані селекційних науководослідних установ. Дослідження проводили за загальноприйнятими в економіці методиками із застосуванням монографічного методу, абстрактно-логічного, а також результатів особистих аналітичних спостережень.

Результати досліджень. На сучасному етапі розвитку селекції та насінництва, формування й функціонування ринку зерна в Україні державним органом, що здійснює офіційну реєстрацію нових сортів в Україні, є Державна система 3 охорони прав на сорти рослин. На рисунку 1 наведена їі структура.

У період 1991-2009 років в Україні сформовано сучасний ринок сортів рослин. Україна спромоглася докорінно поліпшити кількісний і якісний склад сортів рослин, які за результатами державних випробувань визнані придатними до вирощування. За роки незалежності кількість видів сільськогосподарських культур у Державному реєстрі сортів рослин збільшилася в 1,7 разу, від 207-и у 1991 році - до 344-х у 2009 році.

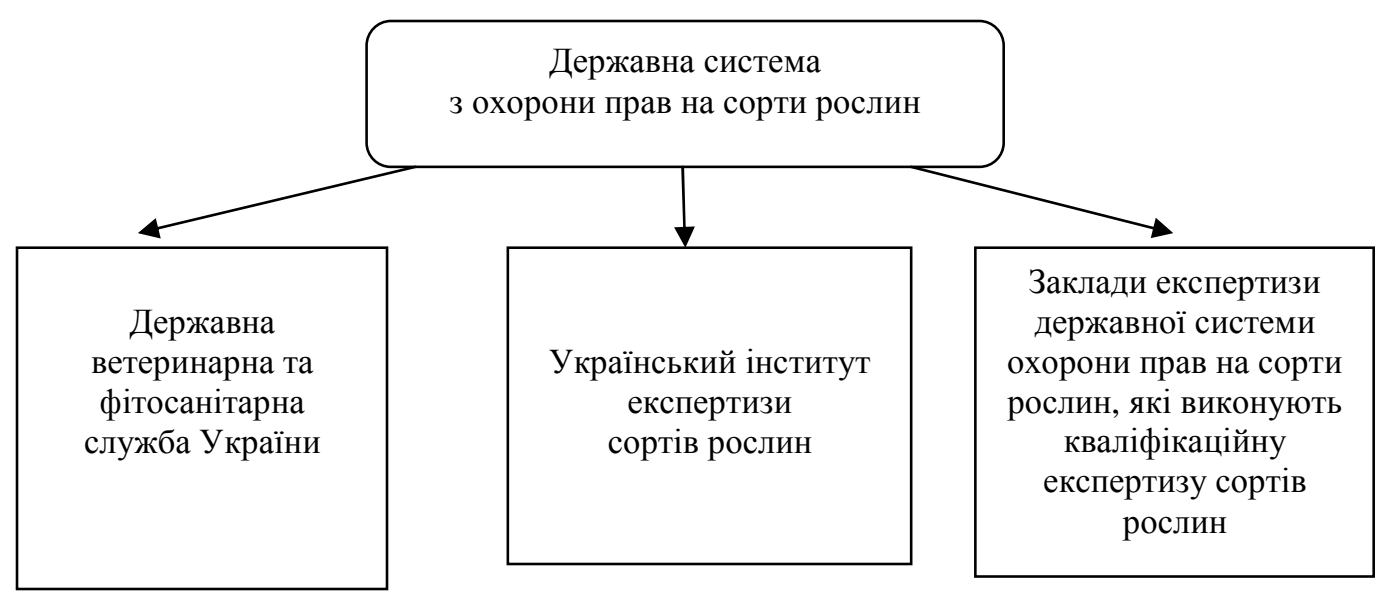

Рис. 1. Структура Державної системи з охорони прав на сорти рослин 


\section{EKOHOMIKA}

Поліпшено якісний склад вітчизняних сортових посівів. Якщо в 1991 році використовувалися 998 сортів, або 53 \% від їх загальної кількості у Державному Реєстрі, то вже 2009 року цей показник зріс до 2677 сортів, тобто $58 \%$ [3].

За короткий проміжок часу створено сприятливі умови для функціонування ринкових відносин у галузі селекції, сортовипробуванні та насінництві. Завершено також врегулювання питань правового забезпечення державної реєстрації майнових і особистих прав, охорони інтелектуальної власності на сорти рослин та проведення державного сортовипробування новостворених сортів [3].

Згідно з чинним законодавством, сорт польової культури, що створений фізичними або юридичними особами, повинен пройти державне сортовипробування відповідно до Закону України «Про охорону прав на сорти рослин» протягом трьох років [2].

Центральним органом виконавчої влади, що забезпечує формування державної політики у сфері охорони прав на сорти рослин відповідно до Указу Президента України «Про затвердження Положення про Державну ветеринарну та фітосанітарну службу України» від 13 квітня 2011року № 464/2011, є «Державна ветеринарна та фітосанітарна служба України (Держветфітослужба України), діяльність якої спрямовується й координується Кабінетом Міністрів України через Міністра аграрної політики та продовольства України (далі - Міністр), входить до системи органів виконавчої влади і забезпечує реалізацію державної політики у галузі ветеринарної медицини, безпечності харчових продуктів, сферах карантину та захисту рослин, охорони прав на сорти рослин, державного нагляду (контролю)...» [9].

Відповідно до ст. 2 зазначеного вище Указу Президента України, «Держветфітослужба України у своїй діяльності керується Конституцією (254к/96-ВР) та законами України, актами Президента України й Кабінету Міністрів України, наказами Міністерства аграрної політики та продовольства України (далі - Міністерство), іншими актами законодавства України, дорученнями Президента України та Міністра, а також цим Положенням» [9].

Основними завданнями Державної системи 3 охорони прав на сорти рослин є: забезпечення розвитку наукового та матеріально-технічного потенціалу у сфері охорони прав на сорти рослин; узгодження формування і виконання міжнародних науково-технічних програм і проектів 3 охорони прав на сорти рослин за спільними координаційними договорами; сприяння розвитку інноваційної діяльності в галузі сортовивчення та охорони прав на сорти рослин; надання державного замовлення на кваліфікаційну експертизу нових сортів рослин; узагальнення практики застосування законодавства про охорону прав на сорти рослин, розробка пропозиції $з$ його вдосконалення; організація прийому заявок, проведення їх експертизи, прийняття рішення щодо них; видача патентів на сорти рослин і свідоцтва про авторство на сорти рослин; ведення Реєстру заявок, Реєстру патентів, Реєстру сортів і забезпечення проведення державної реєстрації заявок, прав на сорти рослин, сортів і підтримувачів сортів рослин; забезпечення опублікування офіційних відомостей про видані патенти на сорти рослин і свідоцтва про авторство на сорти рослин, видача Каталогів сортів рослин, придатних для поширення в Україні; здійснення міжнародного співробітництва у сфері правової охорони сортів рослин і представлення інтересів України 3 питань охорони прав на сорти рослин у міжнародних організаціях відповідно до законодавства та інше [9].

Відповідно, дії, пов'язані $з$ набуттям прав на сорти рослин, регламентуються Законом України «Про охорону прав на сорти рослин» та нормативними актами, виданими на його реалізацію.

Процедура державної реєстрації прав на сорти рослин складається 3 послідовних дій заявника та Держсортслужби: подання заявником до Держсортслужби заявки на сорт рослин $\rightarrow$ експертизи Держсортслужбою заявки i рослин сорту $\rightarrow$ прийняття рішення за заявкою на основі результатів експертизи (рис. 2). Заявка до Держсортслужби подається особою, яка має на це право (заявник), у будь-який час із додержанням вимог до документів заявки на сорт рослин.

Експертиза назви сорту триває впродовж усього строку проведення кваліфікаційної експертизи. Назва сорту затверджується рішенням про державну реєстрацію прав на сорт. У ході експертизи назва сорту, що запропонована заявником у заявці на сорт рослин, перевіряється на тотожність і подібність із назвами всіх доступних загальновідомих сортів із бази даних Держсортслужби, Міжнародного союзу з охорони нових сортів рослин (УПОВ) та публікацій Держав-членів УПОВ [4].

Експертиза новизни сорту проводиться, переважно, на підставі аналізу інформації, що надана Заявником у Заявці щодо першого використання сорту.

Однак до уваги може братися будь-яка офі- 


\section{EKOHOMIKA}

ційна інформація про перше використання сорту, що надійде до Держсортслужби у вигляді заперечення стосовно реєстрації сорту, з офіційних публікацій держав - членів УПОВ або Переліку сортів, що підлягають сортової сертифікації за схемами Організації Свропейського Співробітництва і Розвитку (ОССР) [4].

Постановою КМУ від 19 вересня 2007 р.
№ 1154 «Про внесення змін до постанови КМУ від 19.08.2002 р. №1183» та Постановою КМУ про «Порядок сплати зборів за дії, пов’язані 3 охороною прав на сорти рослин» від 19.08.2002 р. № 1183 регулюється механізм збору відповідних документів і розміри оплати зборів, пов'язаних із набуттям, здійсненням та захистом прав на сорти рослин [6].

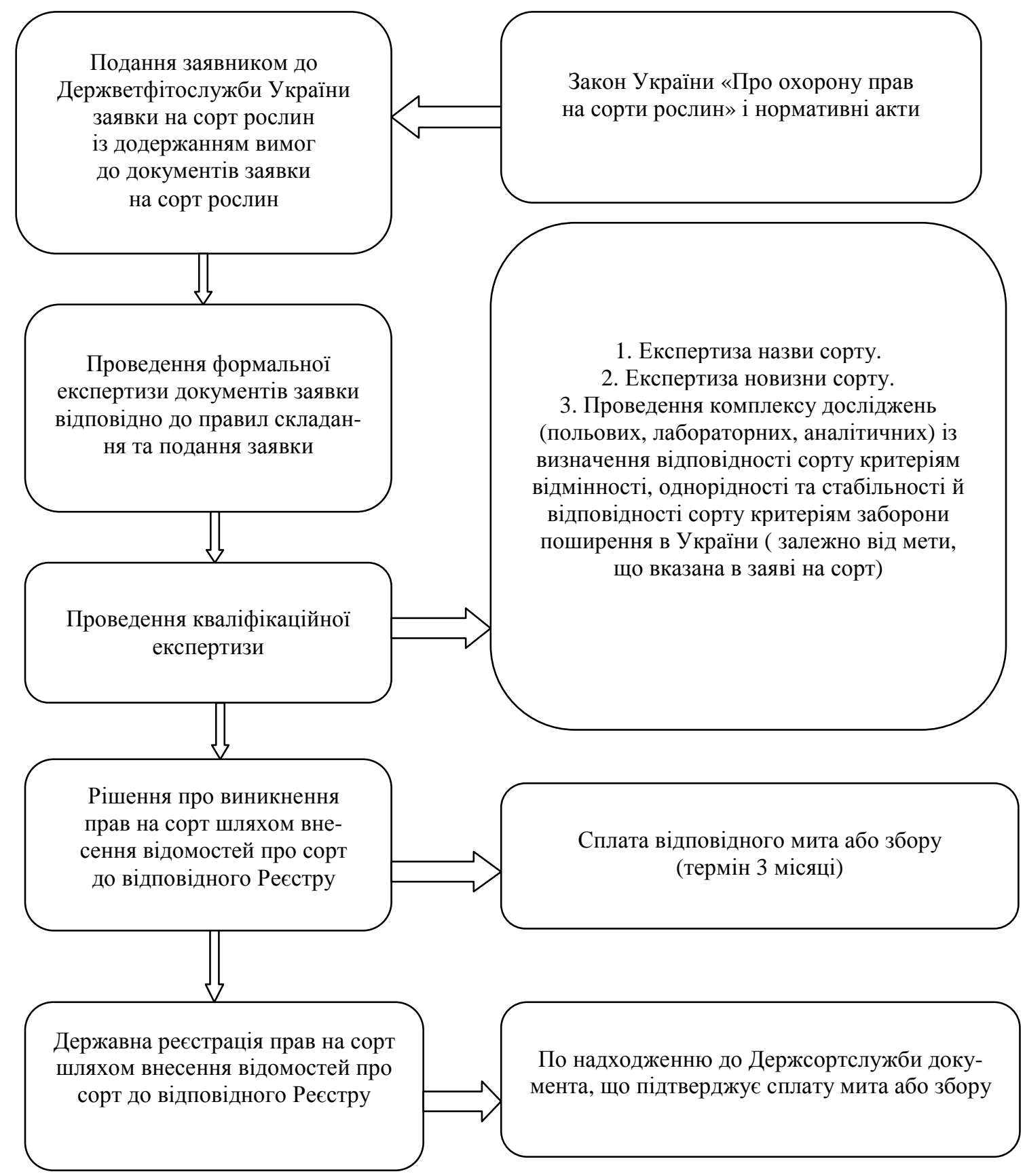

Рис. 2. Схема послідовності дій держсавної реєстрації прав на сорти рослин та проведення кваліфікаційної експертизи

Джерело: складено автором за нормативними положеннями Міністерства аграрної політики та продовольства України, Державної системи з охорони прав на сорти рослин, Українського інституту експертизи сортів рослин. Реєстрації прав, загальні положення [4]. 


\section{EKOHOMIKA}

На підставі проведених досліджень та опрацьованих літературних джерел визначено, що на шляху передачі новоствореного сорту від селекціонера до мережі Державного сортовипробування формується відповідний витратний механізм, а саме:

- подання заявки на сорт;

- проведення кваліфікаційної експертизи;

- формування зборів за дії, пов'язані з охороною прав на сорти рослин;

- визначення вартості насіннєвого матеріалу новоствореного сорту;

- проведення насіннєвої експертизи за місцем установи - оригінатора;

- отримання карантинного сертифіката;

- витрати на відрядження та транспортування насіння до Державної системи сортовипробування (табл. 1-3).

За результатами теоретичних досліджень та реалізації розробленої селекційної програми за останній період у селекційному центрі ПДАА створено 14 сортів пшениці озимої, 9 із яких внесено до Державного реєстру сортів рослин України: Диканька, Левада, Сагайдак, Вільшана, Українка полтавська, Коломак 3, Коломак 5, Оржиця, Царичанка; ще 5 сортів проходять Дер- жавне сортовипробування (Полтавчанка, Кармелюк, Зелений гай, Радивонівка, Аріївка).

Аналіз даних таблиці 1 показав, що фактичні розміри зборів для проведення державної реєстрації прав на сорти рослин та кваліфікаційної експертизи новостворених сортів пшениці озимої Полтавчанка, Кармелюк у селекційному центрі ПДАА становили 39420,00 гривень. У зв'язку з тим, що селекційний центр ПДАА $€$ неприбутковою установою й фінансується з Державного бюджету, відповідно до Постанови КМУ від 09.04.2008 року № 331 «Про доповнення «Порядку сплати зборів за дії, пов'язані 3 охороною прав на сорти рослин», сплачує $10 \%$ від вказаної суми, тобто 3942,00 гривень [7].

Головною умовою проходження Державної експертизи новоствореного сорту є проведення аналізу насіннєвого матеріалу фітосанітарною лабораторією та оформлення карантинного сертифіката на партію вантажу (зазначається кількість насіння). Указом Президента України від 13.04.2011 року № 464/2011 затверджено Положення про Державну ветеринарну та фітосанітарну службу, до якої перейшли повноваження щодо реалізації державної політики у сферах карантину та захисту рослин.

\section{1. Фактичні розміри зборів для проведення державної ресстрації прав на сорти рослин та кваліфікаційної експертизи новостворених сортів пиениці озимої Полтавчанка, Кармелюк у селекційному центрі ПДАА}

\begin{tabular}{|c|c|c|c|c|c|}
\hline \multirow{2}{*}{ № п/п } & \multirow{2}{*}{ Види зборів } & \multicolumn{4}{|c|}{ Розмір зборів, грн } \\
\hline & & $2011 \mathrm{p}$ & $2012 \mathrm{p}$. & 2013 p. & 2014 p. \\
\hline 1 & $\begin{array}{l}\text { За подання заявки } \\
\text { на сорт рослин * }\end{array}$ & 2600,00 & - & - & - \\
\hline \multirow{4}{*}{2} & $\begin{array}{c}\text { За проведення кваліфікаційної експерти- } \\
\text { зи заявки на сорт рослин (за перший і } \\
\text { кожний наступний рік): }\end{array}$ & - & - & - & - \\
\hline & $\begin{array}{c}\text { визначення відповідності сорту критері- } \\
\text { ям відмінності, однорідності та стабіль- } \\
\text { ності в експертних закладах } \\
\text { Держсортслужби } \\
\end{array}$ & 3800,00 & 3800,00 & 3800,00 & - \\
\hline & $\begin{array}{c}\text { визначення відповідності сорту критері- } \\
\text { ям відмінності, однорідності та стабіль- } \\
\text { ності безпосередньо у заявника }\end{array}$ & - & - & - & - \\
\hline & $\begin{array}{c}\text { експертиза на придатність } \\
\text { на поширення сорту }\end{array}$ & 8140,00 & 8140,00 & 8140,00 & - \\
\hline \multirow[t]{2}{*}{3} & $\begin{array}{l}\text { За виникнення майнового права інтелек- } \\
\text { туальної власності на поширення сорту }\end{array}$ & - & - & - & 1000,00 \\
\hline & Разом & 14540,00 & 11940,00 & 11940,00 & 1000,00 \\
\hline
\end{tabular}

Примітка: * Сплачується під час подання заявки на сорт рослин 
ЕКОНОМІКА

2. Вартість послуг у ДУ «Полтавська обласна фітосанітарна лабораторія» за аналіз насіннєвого матеріалу одного зразка новоствореного сорту

\begin{tabular}{|c|c|c|c|c|c|}
\hline № п/п & Послуга & Кількість & Одиниця & Ціна, грн & Вартість, грн \\
\hline 1 & $\begin{array}{c}\text { Аналіз насіннєвого матеріалу } \\
\text { та продукції запасу } \\
\text { на виявлення бур'янів }\end{array}$ & 1 & зразок & 27,27 & 27,27 \\
\hline 2 & $\begin{array}{c}\text { Аналіз насіннєвого матеріалу } \\
\text { та продукції запасу на } \\
\text { виявлення шкідників }\end{array}$ & 1 & зразок & 30,93 & 30,93 \\
\hline & Разом & & & 58,20 \\
\hline
\end{tabular}

Джерело: бухгалтерська звітність селекційного центру ПДАА

\section{3. Прямі витрати, пов'язані з держсавним сортовипробуванням сортів пшениці озимої Полтавчанка, Кармелюк у селекційному центрі ПДАА}

\begin{tabular}{|c|c|c|c|c|}
\hline \multirow{2}{*}{$\begin{array}{l}\text { № } \\
\Pi / \Pi\end{array}$} & \multirow{2}{*}{ Статті витрат } & \multicolumn{3}{|c|}{ Вартість витрат, гривень } \\
\hline & & $2011 \mathrm{p}$ & $2012 \mathrm{p}$ & $2013 \mathrm{p}$ \\
\hline 1 & $\begin{array}{c}\text { Вартість насіння новоствореного сорту*, } \\
\text { (131 кг на один зразок новоствореного } \\
\text { сорту, } 262 \text { кг - на два зразка ); }\end{array}$ & 681,20 & 707,40 & 733,60 \\
\hline 2 & $\begin{array}{l}\text { Надання платних адміністративних послуг } \\
\text { Державною фітосанітарною інспекцією **: } \\
21,75 * 2=43,50 \text { грн }\end{array}$ & 43,50 & 43,50 & 43,50 \\
\hline 3 & $\begin{array}{c}\text { Надання послуг Державною установою } \\
\text { «Обласна фітосанітарна лабораторія»: } \\
58,20 * 2=116,40 \text { грн }\end{array}$ & 116,40 & 116,40 & 116,40 \\
\hline 4 & $\begin{array}{c}\text { Оплата карантинного чи фітосанітарного } \\
\text { сертифіката відповідно до п.6 Постанови } \\
\text { КМУ від 09.06.2011 року № 641: } \\
\text { 38,80*2=77,60 грн } \\
\end{array}$ & 77,60 & 77,60 & 77,60 \\
\hline 5 & $\begin{array}{c}\text { Транспортні витрати ***, } \\
\text { бензин, грн/200 л } \\
\end{array}$ & 2058,00 & 2200,00 & 2200,00 \\
\hline 6 & Витрати на поштові послуги, 5 грн/кг & 1310,00 & 1310,00 & 1310,00 \\
\hline & Разом & 4286,70 & 4454,90 & 4481,10 \\
\hline
\end{tabular}

Примітка: * Насіння новоствореного сорту - це не сорт, але воно має відповідну вартість, яка складається на підставі вартості насіння по генераціях у межах України (перша репродукція).

**Витрати на один зразок новоствореного сорту за надання адміністративних послуг Державною фітоснітарною інспекцією складають: 1) огляд зерна, зернопродуктів - 0,85 грн; 2) інспектування автотранспортних засобів - 20,95 грн, тобто 21,75 гривень.

*** Ціна на бензин визначалася за ринковими цінами за розрахунковий період.

Під час реорганізації в структуру Державної установи «Центральна фітосанітарна лабораторія» (далі ЦФЛ) увійшли Центральна науководослідна карантинна лабораторія, карантинна лабораторія (м. Київ), карантинна лабораторія по Київській області. В межах своїх повноважень ЦФЛ здійснює: проведення фітосанітарної експертизи об'єктів регулювання; аналітику пестицидів та агрохімікатів; надання консультацій та участь в складанні огляду розповсюдження карантинних організмів; моніторинг і контроль за поширенням регульованих шкідливих організмів (табл. 2).

Постановою КМУ від 9 червня 2011 року №641 регулюються розміри плати за надання Державною ветеринарною й фітосанітарною службою, органами та установами, що належать до сфери іiі управління, платних адміністратив- 


\section{EKOHOMIKA}

них послуг із питань карантину рослин (табл. 3) [8].

Прямі витрати відповідно до таблиці 3 за три роки становили 13 222,70 гривень. Аналіз даних таблиць 1-3 показав, що загальна сума витрат на державне сортовипробування сортів пшениці озимої Полтавчанка, Кармелюк у селекційному центрі ПДАА за досліджуваний період визначена у розмірі 17164,70 гривень. За статистичними даними та бухгалтерською звітністю селекційного центру ПДАА, фактичні витрати за 2011-2013 роки на створення сортів пшениці озимої становили 1203000,00 гривень.

Висновок. Дослідження науково-організаційних аспектів структуризації витрат на проведення кваліфікаційної експертизи сортів рослин та державної реєстрації прав на сорти рослин пшениці озимої селекційного центру ПДАА й

\section{БІБЛІОГРАФІЯ}

1. Газета для підприємців АПК «Агробізнес сьогодні». [Електронний ресурс] Режим доступу: http://agro-busness.com.ua/2010-06-11-07-0313/12-2010-06-11-08-31-33/html)

2. Закон України «Про охорону прав на сорти рослин». [Електронний ресурс] Режим доступу: http://zakon4.rada.gov.ua/

3. Захарчук O. В. Формування та розвиток ринку сортів рослин: автореф. дис. ... докт. екон. наук: спец. 08.00.03 «Економіка та управління національним господарством» / Захарчук О. В. Київ, 2010. - 31 с.

4. Міністерство аграрної політики та продовольства України. Державна система 3 охорони прав на сорти рослин. Український інститут експертизи сортів рослин. Реєстрація прав. Загальні положення. [Електронний ресурс] Режим доступу: http://sops.gov.ua/index.php ?page=zakony.

5. Планування витрат на сортовипробування/ [П. Т. Саблук, В. В. Волкодав, М. І. Кісіль, О. В. Захарчук [та інші]; За ред. П. Т. Саблука, В. В. Волкодава, М. І. Кісіля та О. В. Захарчука. - К. : Алефа, 2007. - 303 с.

6. Постанова КМУ від 19 вересня 2007 р. № 1154 «Про внесення змін до постанови КМУ від 19.08.2002p. №1183». [Електронний ресурс] аналіз фактичних витрат на створення сортів показав, що частка виробничих витрат на селекційний процес у загальних витратах на створення нових сортів становить 98,5\%, а державної експертизи - 1,5\%, тобто основний вклад у створенні сорту належить селекціонеру. Варто зауважити, що державна реєстрація сорту й проведення експертизи є необхідною умовою для надання сорту інтелектуальної, господарської та споживчої вартості - лише так сорт набуває комерційного значення і стає товаром. За таких умов виробники насіння і садивного матеріалу та покупці зможуть відтворити й зміцнити оптову торгівлю сортовим насінням, а також скористатися сортовими характеристиками насіння та садивного матеріалу, вибрати найкращі високоврожайні сорти, районовані для даної місцевості, розрахувати й профінансувати майбутні витрати.

Режим доступу: http://zakon4.rada.gov.ua/laws/ show/1154-2007-\%D0\%BF.

7. Постанова КМУ від 09 квітня 2008 р. № 331 «Про доповнення «Порядку сплати зборів за дії, пов'язані 3 охороною прав на сорти рослин». [Електронний ресурс] Режим доступу: http: //kodeksy.com.ua /norm_akt/source-\%D0\%9A\% D0\%9C\%D0\%A3/type-\%D0\%9F\%D0\%BE\%D1 $\% 81 \% \mathrm{D} 1 \% 82 \% \mathrm{D} 0 \% \mathrm{~B} 0 \% \mathrm{D} 0 \% \mathrm{BD} \% \mathrm{D} 0 \% \mathrm{BE} \% \mathrm{D} 0 \%$ B2\%D0\%B0/331-2008-\%D0\%BF-09.04.2008.htm

8. Постанова КМУ від 09 червня 2011 р. № 641 «Про затвердження переліку платних адміністративних послуг, які надаються Державною ветеринарною та фітосанітарною службою, органами та установами, що належать до сфери іï управління, і розміру плати за їх надання».

9. [Електронний ресурс] Режим доступу: http://zakon4.rada.gov.ua /laws/show/641-2011\%D0\%BF/print1406667957727493

10. Указ Президента України «Про затвердження Положення про Державну ветеринарну та фітосанітарну службу України» від 13 квітня 2011 року № 464/2011. [Електронний ресурс] Режим доступу: http://zakon2.rada.gov.ua/laws/ show/464/2011. 